\title{
Forest structure and mortality in an old-growth Jeffrey pine-mixed conifer forest in north-western Mexico
}

\author{
Scott L. Stephens , Samantha J. Gill
}

\begin{abstract}
Over 10 million hectares of forests in the western United States are in need of restoration. Restoration targets benefit from quantitative descriptions but many old growth definitions are qualitative. Quantification of live forest structure and mortality in Jeffrey pine mixed conifer forests in the Sierra San Pedro Martir (SSPM), Mexico, was done to assist in the development of restoration goals and to increase our understanding of old growth forests. Conifer forests in the SSPM have not experienced systematic fire suppression or harvesting making them unusual in western North America. Tree and soil data were collected from a systematic design of plots. High variability characterized all structural attributes measured in this forest. This high variation is probably the result of the relatively intact frequent surface fire regime and no history of harvesting in the sampled area. Cumulative tree mortality was $2.73 .6 \%$; the annual rate of tree mortality was $0.162 \% \mathrm{yr}^{-1}$. Hierarchical cluster analysis determined that $33 \%$ of sampled plots included a relatively small number of large trees, $24 \%$ of plots had bi modal diameter distributions, and $43 \%$ of plots had inverse $\mathrm{J}$ diameter distributions. Separating these categories into seral stages is difficult since all plots included relatively large trees. Stand structure classes include old forest single stratum, young multi strata, and old forest, spatially distinct multi strata. The forests of the SSPM have a great deal of variation and western United States forests with similar species, soils, topography, and disturbance regimes would be expected to have similar variation prior to fire exclusion. Restoration of similar western United States forests should not use uniform restoration targets. Methods must be developed to incorporate more variation in stand level prescriptions. Conservation of the forests in the SSPM is critical because it is one of the last landscape scale, old growth mixed conifer forest with a relatively intact frequent surface fire regime in western North America.
\end{abstract}




\section{Introduction}

Research on old-growth forests in North America has primarily occurred in areas that have not been harvested but have experienced almost a century of fire suppression (Quinby, 1991; Gilliam et al., 1993; Franklin and Kaufmann-Fites, 1996; Ansley and Battles, 1998; Biondi, 1998; Mast et al., 1999; Miller and Urban, 1999; Moore et al., 1999; Stephenson, 1999; Santoro et al., 2001; Barbour et al., 2002; Fulé et al., 2002; Stambaugh et al., 2002). This research has documented significant changes to forest density, composition, and structure over the past 60100 years. Causes include fire suppression, forest harvesting and replanting, livestock grazing, airborne pollutants, and possible changes in climate over the last 100 years. Currently, over 10 million hectares of forests in the western United States (US) are in need of restoration (NWCG, 2001).

Limited research has been done in North American forests that have relatively intact fire regimes (Fulé and Covington, 1998, 1999; Minnich et al., 2000; Swetnam et al., 2001; Heyerdahl and Alvarado, 2002; Stephens et al., 2003). Fulé and Covington (1998, 1999) work has occurred in the Sierra Madre Occidental in north-central Mexico. Forests in this region are composed of Douglas-fir (Pseudotsuga menziesii (Mirb.) Franco), and several species of pine (Pinus spp.), oak (Quercus spp.), juniper (Juniperus spp.), alder (Alnus spp.), madrone (Arbutus spp.), and ash (Fraxinus spp.). Annual summer monsoonal precipitation varied from 600 to $2200 \mathrm{~mm}$ (Fulé and Covington, 1998). Heyerdahl and Alvarado (2002) and Swetnam et al. (2001) also worked in regions with monsoonal climates in north-central Mexico.

In contrast to forests in north-central Mexico, the coniferous forests in northern Baja California are in the Mediterranean climate zone (Pyke, 1972; Markham, 1972; Reyes Coca et al., 1990; Minnich et al., 2000). The Mediterranean climate in the Sierra San Pedro Martir (SSPM) includes higher amounts of summer precipitation than most areas of California (Stephens et al., 2003). Although most of forests in northern Baja California have been grazed to varying levels of intensity (Minnich et al., 1997; Minnich and Franco, 1998), the absence of systematic fire suppression suggests these forests may provide information useful for developing descriptions of reference conditions (Bennett and Adams, 2004) for similar forests in the western US.

The mountain range that dominates this region is the Sierra San Pedro Martir. It is a unique area within the California floristic province in that its forests were influenced by wildfires until the late 1960s (Stephens et al., 2003). Median fire return intervals in Jeffrey pine (Pinus jeffreyi Grev. and Balf)-mixed conifer forests in the SSPM are shorter than 15 years at all composite scales (Stephens et al., 2003), and this is comparable to past fire frequency in similar forests in California (Skinner and Chang, 1996; Stephens, 2001). The seasonality of past fires in the SSPM differs from that in California with the majority of fires recorded in the earlywood portion of annual ring, most fires in Californian forests are recorded in the latewood or dormant periods (Stephens et al., 2003; Stephens and Collins, 2004).

Average forest density in SSPM Jeffrey pine-mixed conifer forests from the analysis of air photos and a limited number (five) of ground plots was reported to be 81 and 82 trees ha ${ }^{1}$, respectively (Minnich et al., 2000). Average basal area from these five ground based plots was $27 \mathrm{~m}^{2}$ ha ${ }^{1}$ and total woody cover (including shrubs) was estimated to be $47 \%$ (Minnich et al., 2000). Savage (1997) estimated tree density in mixed white fir (Abies concolor [Gord. and Glend.] Lindl) forests in the SSPM at 153 trees ha ${ }^{1}$ and average basal area of $26.2 \mathrm{~m}^{2}$ ha ${ }^{1}$. Information on the diameter distributions of SSPM forests has not been published.

Cumulative tree mortality (percentage of standing trees that are dead) estimates in old-growth forests in North America are rare and in the SSPM have been estimated to be $12.7 \%$ from the morphological characteristics of standing snags in mixed conifer forests (Maloney and Rizzo, 2002) and 4.3\% using linear regression equations that related age to the diameter of dead trees in mixed white fir stands (Savage, 1997). The rate of tree mortality was estimated at $0.6 \% \mathrm{yr}^{1}$ in old-growth-mixed conifer forests in the northern Sierra Nevada from the repeat measurement of one large permanent plot established in 1957 (Ansley and Battles, 1998).

No information exists on the distribution of trees and seedlings in old-growth Jeffrey pine forests in the western North America. Tree mortality rates are also scarce. The absence of information has occurred 
because there are few large, coniferous forests in western North America that have not been affected by past management activities, particularly those that once experienced frequent, low-moderate intensity fire regimes. Restoration targets benefit from quantitative descriptions but many old-growth definitions are qualitative (Barbour et al., 2002).

The objectives of this study are to quantify live forest structure and mortality in Jeffrey pine-mixed conifer forests in the SSPM to (1) assist in the development of restoration objectives for similar forests in the western US and (2) to increase our understanding of old-growth forests. Characterization of soil structure and chemistry was done to more fully describe SSPM forests and to permit comparisons to forests with similar geographical characteristics.

\section{Methods}

\subsection{Study location}

The study was conducted in the SSPM National Park, located approximately $120 \mathrm{~km}$ southeast of Ensenada, Baja California, Mexico. Vegetation of the SSPM is composed of conifer forests and shrublands of the Californian floristic province that occur in no other area of Mexico (Minnich et al., 1995, 1997; Minnich and Franco, 1998). Coniferous forests of the SSPM have only recently been described and cover approximately 40,655 ha (Minnich et al., 2000). The SSPM is the southern terminus of the Peninsular Mountain Range that begins at the boundary between the San Jacinto and San Bernardino Mountains in California; approximately $350 \mathrm{~km}$ separates the SSPM from the northern San Bernardino Mountains.

Forests in the SSPM are composed of Jeffrey pine, white fir, sugar pine (Pinus lambertiana Dougl.), lodgepole pine (Pinus contorta var. murrayana Dougl. ex. Loud.), and limited amounts of incense-cedar (Calocedrus decurrens [Torr.] Floren.) and quaking aspen (Populas tremuloides Mich). The most common forest types are Jeffrey pine, Jeffrey pine-mixed conifer, and mixed white fir forests, respectively (Minnich and Franco, 1998). This research was done in Jeffrey pine-mixed conifer forests located at latitude $31^{\circ} 37^{\prime}$, longitude $115^{\circ} 59^{\prime}$, between 2400 and $2500 \mathrm{~m}$ above sea level. Slopes varied between 0 and $25 \%$ and aspect was primarily west and northwest.

Soils in the SSPM are unclassified. The most common parent materials are granites with some soils derived from metamorphic quartz shifts. The mixed conifer forests of the SSPM have experienced neither tree harvesting nor a policy of large-scale fire suppression. Limited fire suppression began in the 1970s but has only consisted of one or two fourperson hand crews in the summer and fall periods (Stephens et al., 2003). Mechanized suppression infrastructure is still not available in this remote region.

Weather data are limited in this area because of its remoteness and the National Observatory of Mexico, which is in the SSPM, has not recorded weather data. A group of temporary weather stations was installed in this range from 1989 to 1992 and annual precipitation in the upper plateau where this work occurred was 55 $70 \mathrm{~cm}$ (Minnich et al., 2000).

\subsection{Soil sampling and analysis}

Soils were collected from a systematic design of plots; the starting point of the grid was selected randomly. Each plot was separated by $200 \mathrm{~m}$ and a total of 49 plots were sampled $(7 \times 7$ grid $)$. Samples were collected from plot center at a depth of $58 \mathrm{~cm}$. Air dry soils were sieved to $<2 \mathrm{~mm}$ and coarse fragment content was determined on a weight basis. The air-dried moisture content was determined and all future measurements were corrected for soil moisture and are based on oven-dry weight.

Particle size analysis was determined by the hydrometer method (Gee and Bauder, 1986). Soil $\mathrm{pH}$ was determined in calcium chloride in a 1:2 soilto-solution mixture (Kalra and Maynard, 1991) using a pH meter. Cation exchange capacity (CEC) was determined by the ammonium acetate $(\mathrm{pH} 7)$ method (Chapman, 1965; Sumner and Miller, 1996) and exchangeable bases in the ammonium acetate filtrate were measured by atomic absorption spectrometry. Available phosphorus was determined by the Bray 1 (dilute acid-fluoride) method (Kalra and Maynard, 1991) and a colorimeter. A subsample of soil was fineground for total carbon and nitrogen determination by combustion gas analyzer (Dumas, 1981). 


\subsection{Live trees and seedlings}

Live trees and seedlings were sampled using the same systematic design of plots used in the soil sampling. All live trees over $2.5 \mathrm{~cm}$ in diameter at $1.37 \mathrm{~m}$ above ground level (DBH) were inventoried using 0.1 ha circular plots. DBH and species of all tress were recorded and each was marked with a permanent tag. The number of seedlings (all trees below $2.5 \mathrm{~cm} \mathrm{DBH}$ ) was tallied by species at each plot.

Upon observation of tree DBH distributions from the 49 plots (Fig. 1), several patterns were apparent. Multivariate hierarchical cluster analysis was used to objectively elucidate and classify the different distribution types (McCune and Grace, 2002). Cluster analysis attempts to classify entities (in this case, plots) into mutually exclusive groups maximizing within-group similarity while minimizing betweengroup similarity (McGarigal et al., 2000). This is accomplished by using the information contained within the variables to generate distance coefficients between each pair of plots (or newly formed groups). Distance coefficients are measures of dissimilarity between plots and small distances result in a joining of those two plots into a group, which, in turn, implies similarity in their distributions.

In cluster analysis, there are a number of techniques available (McGarigal et al., 2000). For this analysis, an agglomerative hierarchical clustering technique was used in which initially, each plot is assigned as an individual cluster. Subsequently, plots with similar distributions are grouped into clusters in a hierarchy of larger clusters as distance coefficients increase. Ultimately, a single cluster remains containing all plots. One output of this technique is a dendrogram, or a cluster tree, effectively depicting the agglomeration sequence and the degree of similarity between clusters containing like plots (McCune and Grace, 2002).

Two requirements for the hierarchical clustering technique are designating the type of distance coefficient and fusion strategy (McCune and Grace, 2002). The Euclidean distance was used as the distance coefficient and complete linkage was used as the fusion strategy. Complete linkage identifies distance values between plots and clusters to be that of the two most widely separated plots. Therefore, when two clusters are joined, their dissimilarity is equal to the greatest dissimilarity for any pair of plots, with one plot in each cluster (McGarigal et al., 2000).

Seven variables were used in the analysis describing tree DBH distributions: minimum, maximum, mean, standard error, median, skewness, and kurtosis. These variables were chosen because they should provide statistics that can be used to separate the DBH distributions using cluster analysis. The distance along the tree, and consequently the number of groups identified at that point, was chosen by the following criteria: (1) observations of the 49 DBH distribution patterns to indicate natural groupings and (2) after the clustering of plots and increasing stability (i.e. branch length) in the tree was evident. Descriptive statistics including average tree density, basal area, and DBH were calculated for each of the groups identified in the hierarchical cluster analysis.

Quantile plots were produced to display the variation in live tree information. De Liocourt's constant ( $q$-factor) was calculated using $10 \mathrm{~cm} \mathrm{DBH}$ classes for all live trees in the 49 plots. The $q$-factor is the ratio of the number of trees in successive diameter classes and is commonly used to describe uneven-aged forests (Daniel et al., 1979).

Cumulative tree mortality is the ratio of the number of standing dead trees (snags) as compared to the total number of standing trees and is expressed as a percentage (Savage, 1997; Maloney and Rizzo, 2002). The rate of tree mortality can be estimated using the following equation (Sheil et al., 1995)

$m=1-\left(\frac{N_{1}}{N_{0}}\right)^{1 / t}$

where $N_{0}$ and $N_{1}$ are the population counts at the beginning and end of the measurement interval, $t$. This model assumes an exponential decline in mortality for a tree cohort through time (Sheil et al., 1995). Data from this work and that collected in the same area in 1998 and 2003 (Stephens, 2004) was used to estimate cumulative tree and the rate of tree mortality.

Forest canopy cover was estimated using ten $100 \mathrm{~m}$ line intercept transects. Each transect had a random starting point and azimuth and was contained within the $7 \times 7$ sampling grid used to sample soils and trees. A clinometer was used to mark the point on the transect when a tree crown was intersected perpendicular to the ground surface, the species of the tree was also recorded. Transect canopy cover was estimated 



9
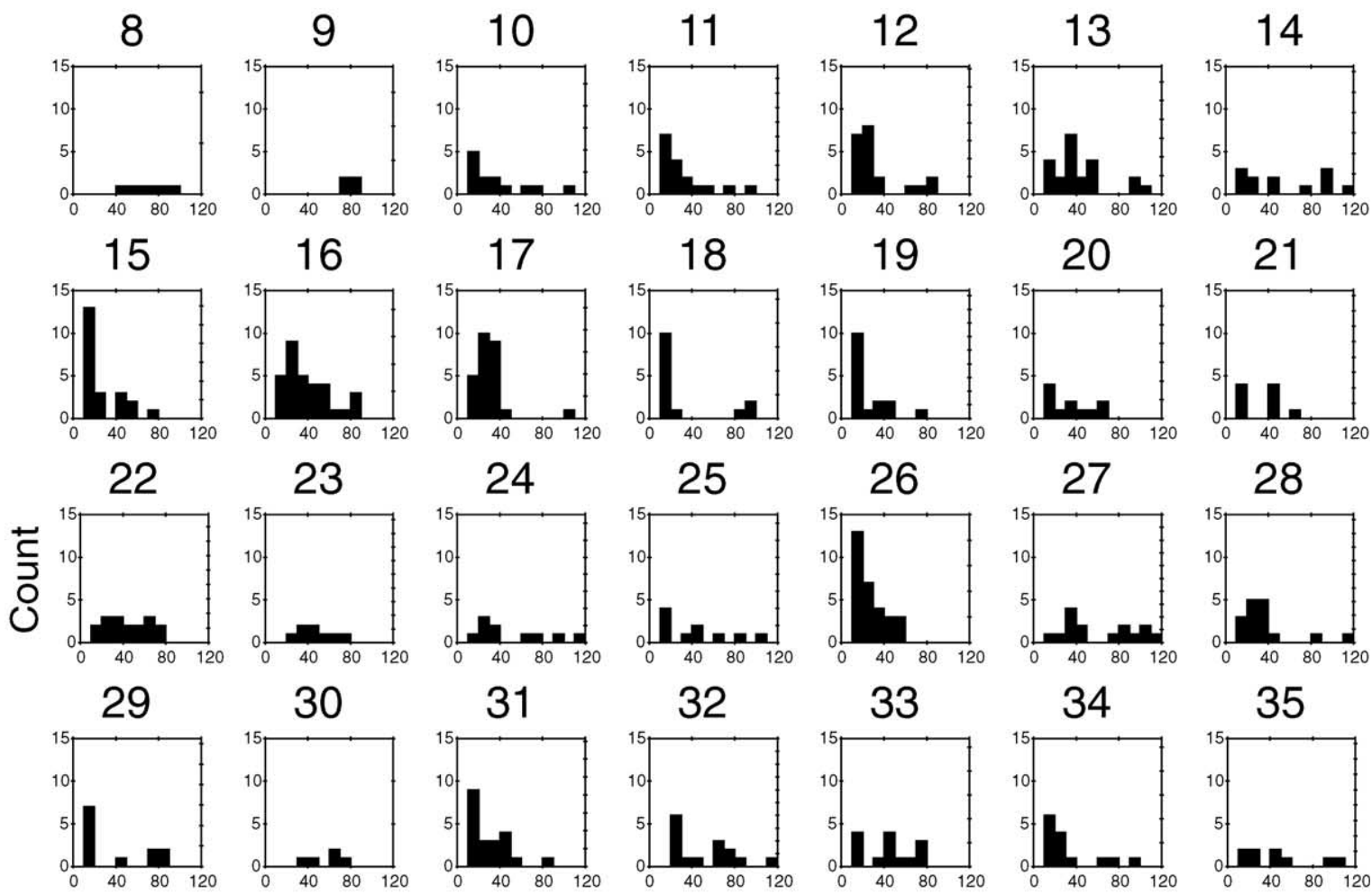

35
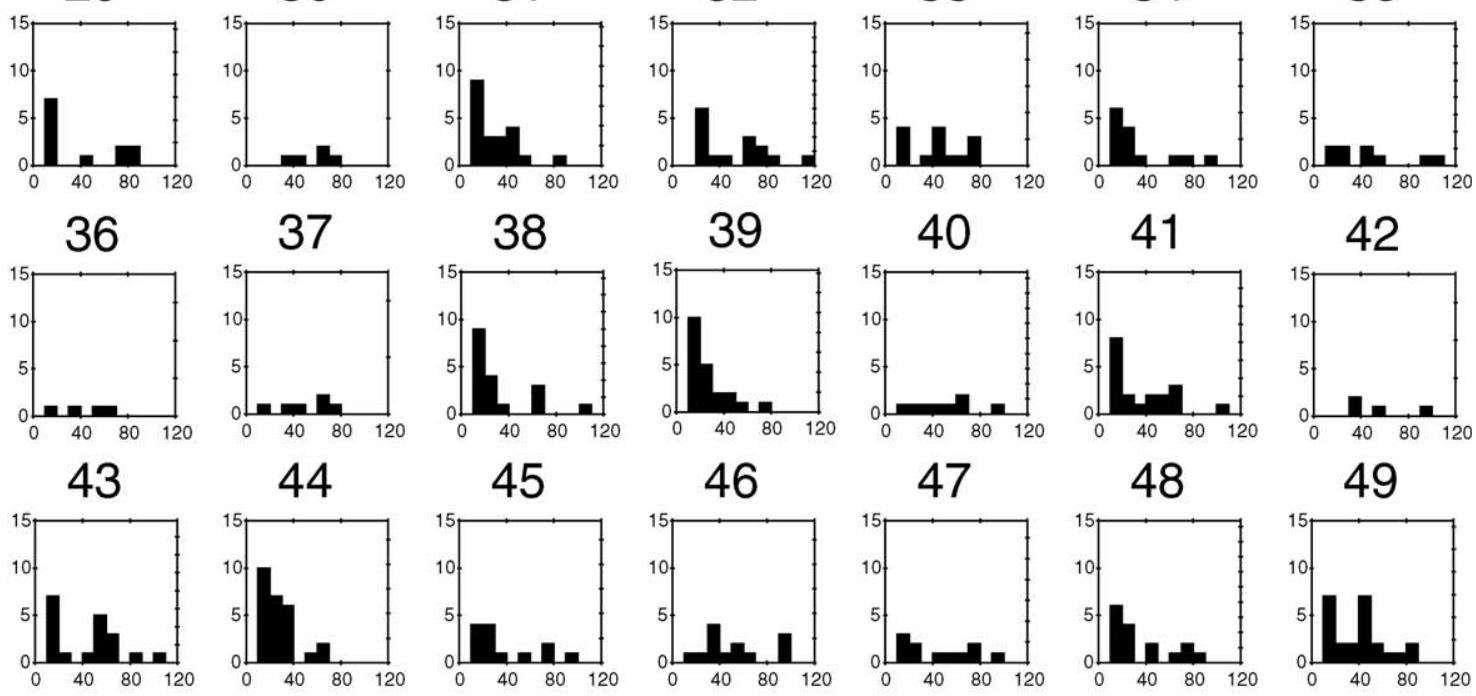

\section{$\mathrm{DBH}(\mathrm{cm})$}

Fig. 1. DBH histograms of the 49 plots in Jeffrey pine mixed conifer forests in the Sierra San Pedro Martir, Mexico; $x$ and $y$ scales are similar $\left(x_{\max } 120, y_{\max } 15\right)$, plot number given on top. 
by the total length (meter) of the transect that was under tree crown divided by $100 \mathrm{~m}$.

\section{Results}

Soils in the sampled areas are Entisols. Soils are shallow, well to excessively drained, and relatively acidic (Table 1). Average organic matter content in the surface soils was $2.27 \%$. Textures range from loamy sands (87\% of samples), sands (6\% of samples), and sandy loams (6\% of samples). Parent material is diorite (P. Zinke, personal communications, 2003).

Soils included a high amount of coarse fragments (i.e. particles $>2 \mathrm{~mm}$ ) (Table 1). Cation exchange capacity values are low and reflect that these soils are sandy with little humus or clay. Calcium dominates the exchange complex (Table 1). Available phosphorus values are relatively high and are similar to Entisols sampled in western Washington (Greinke, 2000).

Live tree diameter histograms of the sampled plots have a great deal of variation (Fig. 1) but when all plots are combined, an inverse-J diameter distribution is produced (Fig. 2). Average DBH of all trees was $32.6 \mathrm{~cm}$ (S.E. $0.9 \mathrm{~cm}$, range $2.5112 \mathrm{~cm}$ ) (Table 2). Sugar pine had the largest average DBH. Ninety-three trees $(12.7 \%)$ had a $\mathrm{DBH}>65 \mathrm{~cm}$, more than twice the mean DBH.

Average tree density was 145.3 trees ha ${ }^{1}$ (S.E. 10.4 trees ha ${ }^{1}$, range 30320 trees ha ${ }^{1}$ ). Jeffrey pine is the most common tree in the sampled area (76\% of plot stocking). Approximately $13 \%$ of plots have tree densities from 220 to 320 trees ha ${ }^{1}$ (Fig. 3). Three plots $(6.1 \%)$ had a tree density $>290$, more than twice the mean density. One plot in a riparian area contained a small number of quaking aspen.

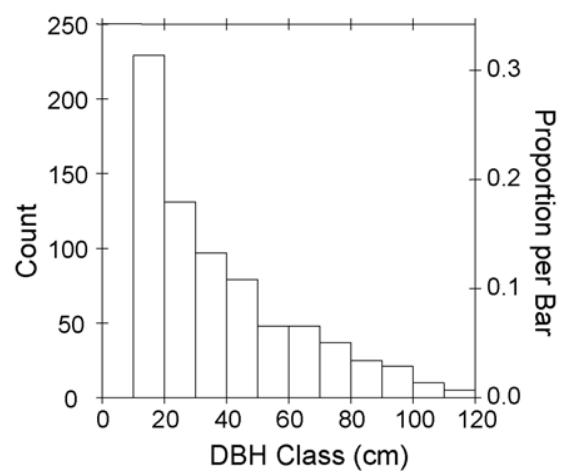

Fig. 2. Histogram of DBH classes for the 49 inventory plots in Jeffrey pine mixed conifer forests in the Sierra San Pedro Martir, Mexico.

Average basal area was $19.9 \mathrm{~m}^{2}$ ha ${ }^{1}$ (range 5.7 $50.7 \mathrm{~m}^{2}$ ha ${ }^{1}$ ). Plot basal area was dominated by Jeffrey pine $(67.1 \%)$, white fir $(23.1 \%)$, and a smaller amount of sugar pine and lodgepole pine (Table 2). Approximately, $20 \%$ of the plots had a basal area below $14 \mathrm{~m}^{2}$ ha ${ }^{1}, 60 \%$ of plots had basal areas from 14 to $22 \mathrm{~m}^{2}$ ha ${ }^{1}$, and $20 \%$ of plots had basal areas of $2250 \mathrm{~m}^{2}$ ha ${ }^{1}$ (Fig. 4). Only two plots (4.1\%) had a basal area $>40 \mathrm{~m}^{2}$ ha ${ }^{1}$, more than twice the mean basal area.

Average seedling density was 124.7 ha ${ }^{1}$ (S.E. 15.7 seedlings ha ${ }^{1}$, range 0470 seedlings ha ${ }^{1}$ ). Eighty-one percent of seedlings were Jeffrey pine followed by white fir $(11 \%)$, sugar pine $(7.7 \%)$, and lodgepole pine $(0.3 \%)$ (Table 2). Six percent of plots had no seedlings, $30 \%$ had a density below 50 ha ${ }^{1}$, $50 \%$ of plots had a density from 50 to 200 ha ${ }^{1}$, and $20 \%$ of plots had a seedling density of 200470 ha ${ }^{1}$ (Fig. 5). Five plots (10.2\%) had a seedling density $>250$, more than twice the mean seedling density.

Hierarchical cluster analysis identified five groups of plots with similar characteristics (Fig. 6). Group 1

Table 1

Chemical and physical soil characteristics from Jeffrey pine mixed conifer forests in the Sierra San Pedro Martir, Mexico

\begin{tabular}{|c|c|c|c|c|c|c|c|c|c|c|c|c|c|c|}
\hline & \multirow{2}{*}{$\begin{array}{l}\text { Percent } \\
>2 \mathrm{~mm}\end{array}$} & \multirow[t]{2}{*}{$\mathrm{pH}$} & \multicolumn{2}{|l|}{ Total } & \multirow{2}{*}{$\begin{array}{l}\text { Bray } P \\
\left(\mathrm{mg} \mathrm{kg}^{1}\right)\end{array}$} & \multicolumn{5}{|c|}{ Exchangeable cations $\left(\mathrm{cmol}_{\mathrm{c}} \mathrm{kg}{ }^{1}\right)$} & \multirow[t]{2}{*}{ Saturation } & \multicolumn{3}{|l|}{ Texture } \\
\hline & & & $N(\%)$ & $C(\%)$ & & CEC & $\mathrm{Ca}^{2+}$ & $\mathrm{Mg}^{2+}$ & $\mathrm{K}^{+}$ & $\mathrm{Na}^{+}$ & & Sand $(\%)$ & Silt (\%) & Clay (\%) \\
\hline Average & 26.47 & 5.32 & 0.08 & 2.27 & 40.18 & 5.80 & 3.34 & 0.42 & 0.29 & 0.02 & 68.34 & 82.44 & 12.78 & 4.78 \\
\hline Maximum & 54.55 & 6.85 & 0.24 & 8.01 & 154.44 & 15.02 & 13.09 & 0.89 & 0.63 & 0.06 & 105.52 & 89.56 & 30.00 & 10.16 \\
\hline Minimum & 11.89 & 3.86 & 0.02 & 0.41 & 13.86 & 2.66 & 1.31 & 0.16 & 0.12 & 0.01 & 32.49 & 64.56 & 8.36 & 1.84 \\
\hline S.E. & 1.32 & 0.08 & 0.01 & 0.43 & 3.57 & 0.37 & 0.37 & 0.03 & 0.02 & 0.00 & 2.49 & 0.72 & 0.64 & 0.22 \\
\hline
\end{tabular}


Table 2

Tree and seedling characteristics from 49 plots in Jeffrey pine mixed conifer forests in the Sierra San Pedro Martir, Mexico

\begin{tabular}{|c|c|c|c|c|c|}
\hline & Jeffrey pine & White fir & Sugar pine & Lodgepole pine & Total \\
\hline Total number of trees & 541 & 129 & 43 & 17 & 730 \\
\hline \multicolumn{6}{|l|}{$\mathrm{DBH}(\mathrm{cm})$} \\
\hline Average (S.E.) & $30.8(1.0)$ & $38.6(2.6)$ & $40.4(4.6)$ & $26.4(4.5)$ & $32.6(0.9)$ \\
\hline Median & 23.8 & 34.7 & 32.5 & 21.5 & 25.7 \\
\hline Minimum/maximum & $2.5 / 112$ & $3.4 / 110.1$ & $3.8 / 109$ & $4.7 / 69.6$ & $2.5 / 112$ \\
\hline \multicolumn{6}{|l|}{ Basal area $\left(\mathrm{m}^{2}\right.$ ha $\left.{ }^{1}\right)$} \\
\hline Average & 13.35 & 4.60 & 1.67 & 0.28 & 19.9 \\
\hline Percentage & 67.1 & 23.1 & 8.4 & 1.4 & 100 \\
\hline Minimum/maximum & $5.7 / 9.85$ & $0 / 8.59$ & $0 / 6.36$ & $0 / 8.57$ & $5.7 / 50.7$ \\
\hline \multicolumn{6}{|l|}{ Tree density (ha ${ }^{1}$ ) } \\
\hline Average (S.E.) & $110.4(10.3)$ & $26.3(5.2)$ & $8.8(2.7)$ & $3.5(2.0)$ & $145.3(10.4)$ \\
\hline Median & 80 & 10 & 0 & 0 & 140 \\
\hline Minimum/maximum & $0 / 290$ & $0 / 160$ & $0 / 110$ & $0 / 90$ & $30 / 320$ \\
\hline \multicolumn{6}{|l|}{ Seedling density (ha ${ }^{1}$ ) } \\
\hline Average (S.E.) & $101.2(13.5)$ & $13.5(2.9)$ & $9.6(3.3)$ & $0.4(0.3)$ & $124.7(15.7)$ \\
\hline Median & 60 & 0 & 0 & 0 & 100 \\
\hline Minimum/maximum & $0 / 410$ & $0 / 80$ & $0 / 140$ & $0 / 10$ & $0 / 470$ \\
\hline
\end{tabular}

S.E.: standard error of the mean.

includes a small number of plots with a few large trees. Group 2 includes plots with a small number of large trees but with a larger DBH range than in group 1. Group 3 includes plots with bimodal diameter distributions. Group 4 includes plots with an inverse-J distribution with high diameter averages. Group 5 also includes plots with an inverse-J distribution but with a lower average diameter and a smaller diameter range when compared to group 4 (Table 3). De Liocourt's constant ( $q$-factor) for groups

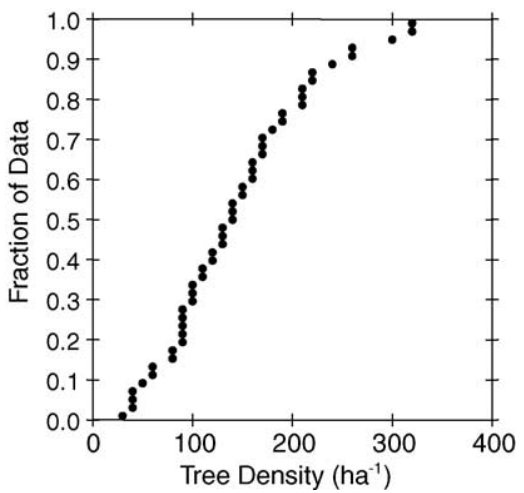

Fig. 3. Tree density (ha ${ }^{1}$ ) distribution from the 49 inventory plots in Jeffrey pine mixed conifer forests in the Sierra San Pedro Martir, Mexico.
4 and 5 was 3.08 and 1.56 , respectively (Table 4). De Liocourt's constant for all 49 plots was 1.50 (Table 4). The five groups classified by the clusters form a mosaic across the landscape (Fig. 7).

Cumulative tree mortality in 1998 and 2003 was 2.70 and $3.61 \%$, respectively. The rate of mortality (Equation 3) from 1998 to 2003 was $0.162 \% \mathrm{yr}^{1}$. The rate of mortality of seedlings (DBH below $2.5 \mathrm{~cm}$ ) cannot be estimated from this work because they were not re-sampled in 2003.

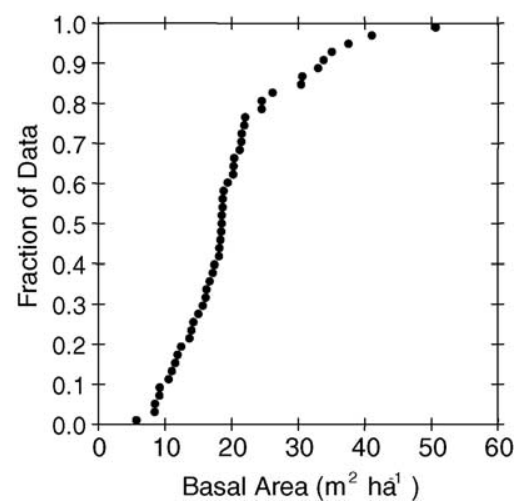

Fig. 4. Tree basal area $\left(\mathrm{m}^{2}\right.$ ha $\left.{ }^{1}\right)$ distribution from the 49 inventory plots in Jeffrey pine mixed conifer forests in the Sierra San Pedro Martir, Mexico. 


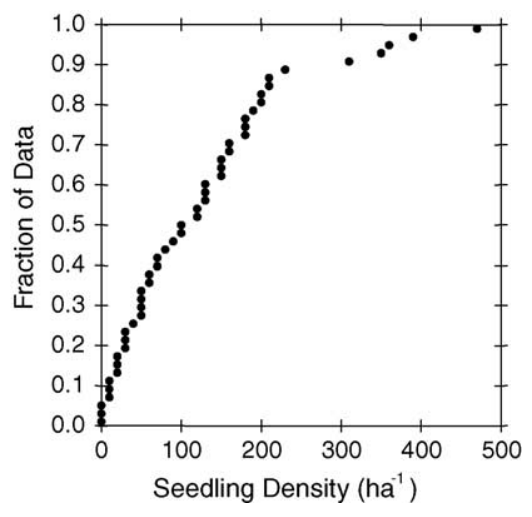

Fig. 5. Seedling density (ha ${ }^{1}$ ) distribution from the 49 inventory plots in Jeffrey pine mixed conifer forests in the Sierra San Pedro Martir, Mexico.

Average canopy cover was $25.3 \%$ (S.E. $3.81 \%$, range $1449.5 \%$ ). The transect with a canopy cover of 49.5\% passed through a seasonal creek (Lucky Creek). Jeffrey pine was the species that dominated canopy cover (average of $19.2 \%$ ) followed by white fir (average of 5.6\%).

\section{Discussion}

Old-growth forests are of interest because of their rarity, what they can tell us about human-induced change, and their use as management goals for restoration (Barbour et al., 2002). Intact, old-growth forests are extremely rare in western North America because of the management practices of fire suppression and forest harvesting. As a result, there are few forests in western North America that could serve as models or references (Bennett and Adams, 2004) for forests functioning under the continuing influence of climate variation and frequent fires (Stephens et al., 2003).

Soil chemistry and texture in this study are typical of granite-derived soils in similar forests in California (Potter, 1998). Soils sampled in the SSPM were shallow and poorly weathered, perhaps due to a combination of climate and topographic position. Texture reflects the low amount of weathering. The CEC reflects the high amount of sand and low organic content (Table 1). The base saturation values are within the range of soils sampled in the Sierra Nevada (Greinke, 2000). Phosphorus concentrations

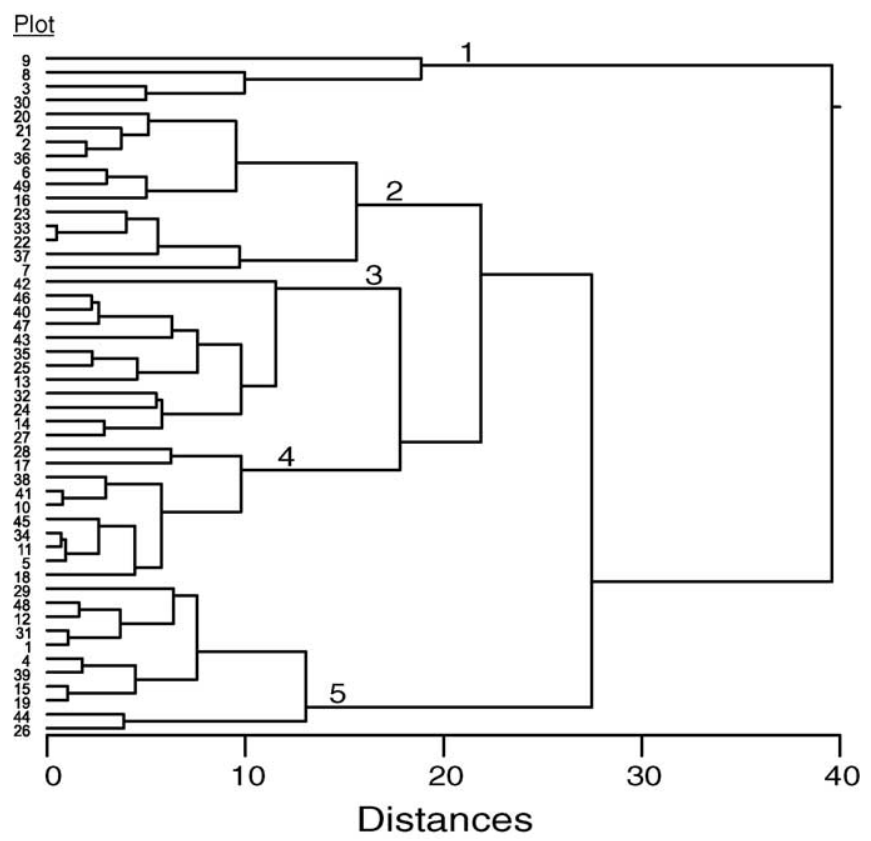

Fig. 6. Multivariate hierarchical cluster analysis of DBH histograms from the 49 inventory plots in Jeffrey pine mixed conifer forests in the Sierra San Pedro Martir, Mexico. Numbers along branches indicate groups (see Table 3). 
Table 3

Summary statistics for DBH classes by groups identified in cluster analysis and for all 49 plots combined in Jeffrey pine mixed conifer forests in the Sierra San Pedro Martir, Mexico

\begin{tabular}{|c|c|c|c|c|c|c|}
\hline & Group 1 & Group 2 & Group 3 & Group 4 & Group 5 & Total \\
\hline Number of plots & 4 & 12 & 12 & 10 & 11 & 49 \\
\hline Plot numbers & $3,8,9,30$ & $\begin{array}{l}2,6,7,16, \\
2023,33, \\
36,37,49\end{array}$ & $\begin{array}{l}13,14,24,25 \\
27,32,35,40 \\
42,43,46,47\end{array}$ & $\begin{array}{l}5,10,11,17 \\
18,28,34 \\
38,41,45\end{array}$ & $\begin{array}{l}1,4,12,15, \\
19,26,29, \\
31,39,44,48\end{array}$ & \\
\hline Number of trees & 18 & 153 & 148 & 167 & 244 & 730 \\
\hline Minimum DBH & 30 & 10 & 10 & 10 & 10 & 10 \\
\hline Maximum DBH & 90 & 80 & 110 & 110 & 80 & 110 \\
\hline Mean DBH & 62.22 & 37.39 & 44.66 & 28.92 & 24.63 & 33.27 \\
\hline S.E. & 3.92 & 1.73 & 2.43 & 1.90 & 1.19 & 0.92 \\
\hline Median DBH & 65 & 40 & 40 & 20 & 20 & 30 \\
\hline Skewness & 0.40 & 0.30 & 0.62 & 1.57 & 1.43 & 1.04 \\
\hline Kurtosis & 0.62 & 0.96 & 0.77 & 1.66 & 1.31 & 0.23 \\
\hline
\end{tabular}

are similar to those found in Entisols in western Washington but are higher than those found in Alfisols derived from either andesitic mudflow or granitic/granodiorite parent materials in the northern Sierra Nevada, California (Hart et al., 1992; Greinke, 2000).

High variability characterized all tree and seedling attributes measured in this Jeffrey pine-mixed conifer forest (Figs. 1, 35 and 7). This high amount of variability is probably the result of the relatively intact frequent fire regime and lack of harvesting in this forest. High variability in surface fuel loads (Stephens, 2004) would produce equally diverse fire behavior and effects, and this would probably maintain high spatial heterogeneity if the forest continues to burn under a low-moderate intensity fire regime.

The forests in the Lake Tahoe Basin share several common characteristics with forests in the SSPM including vegetation, soils, and fire frequency. Forest density and basal area in mixed Jeffrey pine forests on the east-side of the Lake Tahoe Basin, Nevada, before Euro-American contact was estimated at 68 trees ha ${ }^{1}$ and $26 \mathrm{~m}^{2}$ ha ${ }^{1}$ (Taylor, 1998). The forests sampled in this study had a mean density and basal area of 145.3 trees ha ${ }^{1}$ and $19.9 \mathrm{~m}^{2}$ ha ${ }^{1}$. The difference in tree density can be partially explained by the

Table 4

De Liocourt's constant ( $q$ factor) for all plots and groups 4 and 5 identified in cluster analysis in Jeffrey pine mixed conifer forests in the Sierra San Pedro Martir, Mexico

\begin{tabular}{|c|c|c|c|c|c|c|}
\hline \multirow[t]{2}{*}{ DBH class $(\mathrm{cm})$} & \multicolumn{2}{|l|}{ Group 4} & \multicolumn{2}{|l|}{ Group 5} & \multicolumn{2}{|l|}{ All trees } \\
\hline & Number of trees & $q$ factor & Number of trees & $q$ factor & Number of trees & $q$ factor \\
\hline 014.9 & 63 & 15.75 & 105 & 1.94 & 229 & 1.75 \\
\hline 1524.9 & 4 & 4.00 & 54 & 1.80 & 131 & 1.35 \\
\hline 2534.9 & 1 & 0.03 & 30 & 1.36 & 97 & 1.23 \\
\hline 3544.9 & 39 & 1.63 & 22 & 2.00 & 79 & 1.65 \\
\hline 4554.9 & 24 & 2.67 & 11 & 1.83 & 48 & 1.00 \\
\hline 5564.9 & 9 & 1.50 & 6 & 0.67 & 48 & 1.30 \\
\hline 6574.9 & 6 & 0.75 & 9 & 1.29 & 37 & 1.48 \\
\hline 7584.9 & 8 & 1.60 & 7 & & 25 & 1.19 \\
\hline 8594.9 & 5 & 2.50 & & & 21 & 2.10 \\
\hline 95104.9 & 2 & 0.33 & & & 10 & 2.00 \\
\hline 105114.9 & 6 & & & & 5 & \\
\hline Average & & 3.08 & & 1.56 & & 1.50 \\
\hline S.D. & & 4.6 & & 0.48 & & 0.36 \\
\hline
\end{tabular}

Total number of trees in group $4 \quad 167$, group $5 \quad 244$, all trees 730 . S.D.: standard deviation. 

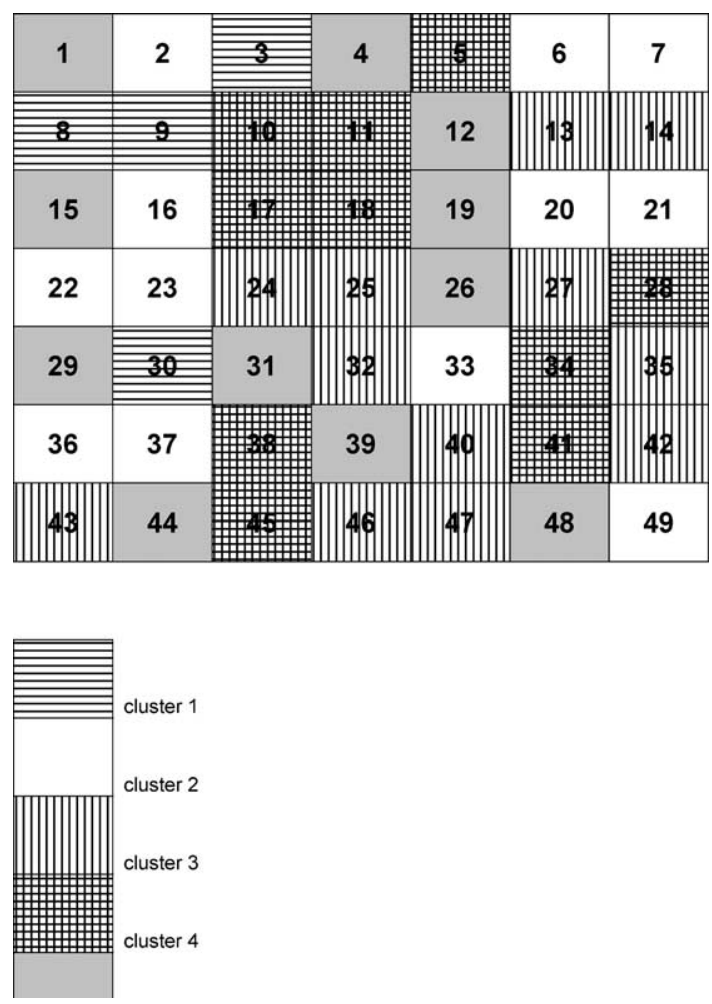

Fig. 7. Assignment of plots to the multivariate hierarchical cluster analysis to illustrate geographic arrangement of cluster groups in Jeffrey pine mixed conifer forests in the Sierra San Pedro Martir, Mexico.

limitations of sampling old stumps to reconstruct past forest density on the east-side of Lake Tahoe. This study included all trees greater than $2.5 \mathrm{~cm}$ DBH whereas Taylor (1998) was only able to collect information from larger stumps. If the lower DBH limit is raised to $30 \mathrm{~cm}$ in this work, this produces an average tree density of 65 trees ha ${ }^{1}$. The Jeffrey pinemixed conifer forests sampled in this work probably have lower tree densities than those sampled by Taylor (1998) because stump preservation on the east-side of Lake Tahoe probably allowed for adequate sampling of trees up to $30 \mathrm{~cm} \mathrm{DBH}$.

The Pinus:Abies ratio was 4:1 in the forests of the east side of Lake Tahoe (Taylor, 1998) and this is very similar to the forests analyzed in this study (4.2 1). Taylor's (1998) reconstructed density values are similar to the values for modern old-growth Jeffrey pine stand overstories in the Lake Tahoe Basin (Barbour et al., 2002). The density of overstory trees $(>40 \mathrm{~cm} \mathrm{DBH}$ as defined by Barbour et al., 2002) in this study was 48 trees ha ${ }^{1}$, approximately $25 \%$ lower than that reported in the Lake Tahoe Basin (Barbour et al., 2002). Modern old-growth Jeffrey pine stands in the Lake Tahoe Basin have much higher understory $(\mathrm{DBH}<40 \mathrm{~cm}$ ) tree densities (averaging 222 trees ha ${ }^{1}$ ) than those in the SSPM (averaging 97 trees ha ${ }^{1}$ ) because of fire suppression. Changing climates over the last century could have also influenced current forest structure (Millar and Woolfenden, 1999).

In 1932, mixed Jeffrey pine forests in the San Bernardino Mountains of southern California had an average density of 93 trees ha ${ }^{1} \quad$ (including trees $>12 \mathrm{~cm} \mathrm{DBH}$ ) (Minnich et al., 1995). Tree density from the present study for all trees $>12 \mathrm{~cm}$ DBH was 108 trees ha ${ }^{1}$ which is similar to that reported in the San Bernardino Mountains before largescale fire suppression or harvesting. In 1932, the mixed Jeffrey pine forests in the San Bernardino Mountains had a heterogeneous distribution of stem diameters, a characteristic that still exists in the forests in the SSPM.

Cumulative mortality reported in the present study was similar to that reported in SSPM-mixed white fir stands (Savage, 1997) but is much lower than that reported in similar forests by Maloney and Rizzo (2002). The rate of mortality reported in this work $\left(0.162 \% \mathrm{yr}^{1}\right)$ is lower than the $0.6 \% \mathrm{yr}^{1}$ in oldgrowth-mixed conifer forests in the northern Sierra Nevada (Ansley and Battles, 1998) even though the time period of the estimate (1998 2003) coincided with one of the highest mortality episodes in the last century in the SSPM (Stephens, 2004). The much higher mortality rates from the denser, fire-suppressed forests in the northern Sierra Nevada were probably produced by high competition in the stem exclusion phase of stand development.

The structure of the Jeffrey pine-mixed conifer forests in the SSPM is diverse. Thirty-three percent of plots included a relatively small number of large trees, $24 \%$ of plots had bi-modal diameter distributions, and the remaining $43 \%$ of plots had inverse-J diameter distributions with many more small trees than large trees (Table 3). Separating these categories into seral stages is difficult since all plots included relatively large trees (Table 5). Tree age data are not provided in this study but similarly sized Jeffrey pine and white fir in the SSPM have been aged at 250400 years old (Stephens et al., 2003). 
The plots that had an inverse-J distribution (groups 4 and $5,43 \%$ of total) could be classified as multi-aged because of their relatively wide range of tree sizes. The plots that contained a relatively small number of large trees could be classified as having a narrower age distribution (groups 1 and 2, 33\% of total). All plots together described an old-growth forest structure, since this area has had very few management inputs except livestock grazing and limited fire suppression. Indeed, this old-growth Jeffrey pine-mixed conifer forest includes components of all seral stages in the majority of the sampled plots. Similarly, southwestern US ponderosa pine (Pinus ponderosa Laws.) forests subjected to frequent, low-moderate intensity fire regimes have a very fine-grained pattern of disturbance and mortality at a scale of small patches or single trees (Mast et al., 1999).

Another forest classification system emphasizes existing forest conditions and processes versus the seral stage of development (Oliver, 1981; O'Hara et al., 1994, 1996). This system attempts to describe forest structure and to link it to stand development processes that create and maintain it and has the advantage of describing current vegetation structure that is increasingly the basis for describing resource management objectives (O'Hara et al., 1996).

Three of O'Hara et al. (1996) stand structure classes are apparent in the SSPM data (1) old forest single-stratum, (2) young multi-strata, and (3) old forest multi-strata with some modifications. Old forest single-stratum describes a single-stratum of medium to large, old trees with one or more cohorts; groups 1 and 2 have these characteristic (Fig. 1). This structure can be maintained with frequent, low-moderate intensity fire regimes (O'Hara et al., 1996).

Young multi-strata include stands with two or more cohorts with an assortment of trees sizes and canopy strata present but very large trees are absent. This structure is similar to that of group 3 except these SSPM plots do include a few very large trees. This structure could be created after periodic disturbances including moderate intensity fires or harvest events (O’Hara et al., 1996).

Old forest multi-strata describe stands that are multi-aged with an assortment of trees sizes and canopy strata present including large, old trees. Groups 4 and 5 (Fig. 1) are multi-sized and include many more small trees versus larger trees (inverse-J

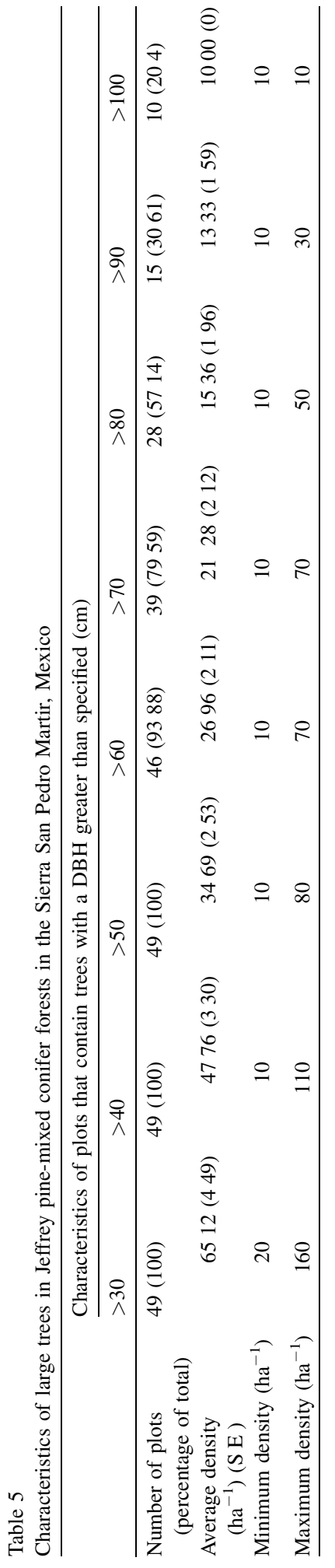


distribution). One complication of this stand structure class is the SSPM does not have many multi-strata stands. The relatively intact disturbance regime has developed a forest structure where different canopy strata are separated by space, resulting in a patchy distribution of trees. A new stand structure class of old forest, spatially distinct multi-strata could be assigned.

In many areas of California with similar Jeffrey pine-mixed conifer forests, past harvesting has removed the largest trees and fire suppression and other factors have increased understory tree density (Minnich et al., 1995, 2000; Savage, 1997; Stephens, 2001; Barbour et al., 2002). If active management were to include targeted thinning of young trees and prescribed fire, it is probable that succession could be accelerated to produce old-growth conditions and precontact stand structure might be approached in the Tahoe Basin and elsewhere in Alta California (Zack et al., 1999; Barbour et al., 2002). These active management prescriptions would have to incorporate within-stand variation.

\section{Conclusions}

The SSPM is unique within the California floristic province in that this large, forested area has not been affected by logging or systematic fire suppression. Conservation of the forests in the SSPM is therefore critical because it is one of the last landscape-scale, old-growth-mixed conifer forests in western North America. However, if recent (1970 to present) fire suppression activities are maintained or expanded, this will likely result in increased fire hazards and associated problems with forest sustainability (Stephens et al., 2003).

The variable distribution of live trees observed in this study argues for variability in restoration targets across similar forest landscapes. Restoration of western US forests should not use a uniform restoration prescription such as all stands must have a specified number of large trees. An improvement in management guidelines would be to allow spatial heterogeneity in desired future conditions. This would require flexibility in the application of restoration treatments, something that is rare in US federal land management.
Many forest restoration and management plans, both federal and private, specify average stand conditions over very large spatial scales (USDA, 2004). This has the advantage of simplicity but is not supported by this data collected from the SSPM. The Jeffrey pine-mixed conifer forests in the SSPM have a great deal of variation in forest structure. It is likely that similar forests in the US also had this high amount of variation because they once experienced similar disturbance regimes and many had comparable abiotic environments.

\section{Acknowledgments}

We thank Ernesto Franco for his assistance in setting up this project. We thank Kevin O'Hara and Danny Fry for reviewing this paper, Danny also provided data analysis. Jason Kirschenstein, Gary Roller, Brett Goforth, Natalie Guzman, Jason Moghaddas, Ken Herman, Bret Sampson, and Ralph Boniello provided field assistance. Jim Bertenshaw and Emily Moghaddas assisted in soil analysis. Discussions with John Battles about data analysis were very helpful. We appreciated the review comments from two referees that improved the paper. This project was supported by USDA Agricultural Experiment Station funds from the University of California, Berkeley, and California Polytechnic State University San Luis Obispo.

\section{References}

Ansley, J.S., Battles, J.J., 1998. Forest composition, structure, and change in an old growth mixed conifer forest in the northern Sierra Nevada. J. Torrey Soc. 125, 297308.

Barbour, M., Kelley, E., Maloney, P., Rizzo, D., Royce, E., Fites Kaufmann, J., 2002. Present and past old growth forests of the Lake Tahoe Basin., Sierra Nevada. U.S. J. Veg. Sci. 13, 461472.

Bennett, L.T., Adams, M.A., 2004. Assessment of ecological effects due to forest harvesting: approaches and statistical issues. J. Appl. Ecol. 41, 585598.

Biondi, F., 1998. Twentieth centaury growth trends at the Gus Pearson Natural Area, Arizona, USA. In: Dallmeier, F., Co miskey, J.A. (Eds.), Forest Biodiversity in North, Central and South America, and the Caribbean: Research and Monitoring. Man and the Biosphere Series, vol. 21. Parthenon Pub. Group, New York, pp. 107147. 
Chapman, H.D., 1965. Cation exchange capacity. In: Black, C.A. (Ed.), Methods of Soil Analysis, Part 2. American Society of Agronomy, Madison, WI, pp. 891900.

Daniel, T.W., Helms, J.A., Baker, F.R., 1979. Principles of Silviculture, second ed. McGraw Hill Publishing Company, New York, NY, 500 pp..

Dumas, J.B., 1981. Sur les procédés de l'analyse organique. Annal. Chim. 47, 195213.

Franklin, J.F., Kaufmann Fites, J.A., 1996. Assessment of late successional forests in the Sierra Nevada. Sierra Nevada Ecosystem Project: Final Report to Congress, vol. II. Assess ments and Scientific Basis for Management Options, University of California, Davis, Centers for Water and Wildland Resources, Davis, CA, pp. 627662.

Fulé, P.Z., Covington, W.W., 1998. Spatial patterns of Mexican pine oak forests under different recent fire regimes. Plant Ecol. 134, 197209.

Fulé, P.Z., Covington, W.W., 1999. Fire regime changes in La Michilia Biosphere Reserve, Durango Mexico. Conserv. Biol. 13, 640652.

Fulé, P.Z., Covington, W.W., Moore, M.M., Heinlein, T.A., Waltz, A.E.M., 2002. Natural variability in forests of Grand Canyon. U.S.A. J. Biogeogr. 29, 3147.

Gee, G.W., Bauder, J.W., 1986. Particle size analysis. In: Klute, A. (Ed.), Methods of Soil Analysis, Part 1, Agron, vol. 9. American Society of Agronomy, Madison, WI, pp. 383411.

Gilliam, F.S., Yurish, B.M., Goodwin, L.M., 1993. Community composition of an old growth longleaf pine forest: relationship to soil texture. Bull. Torrey Club 120, 287294.

Greinke, E.E.Y., 2000. Wood decomposition and nutrient dynamics in California and Washington forests. M.S. Thesis. Department of Environmental Science, Policy, and Management, University of California, Berkeley, CA, 111 pp.

Hart, S.C., Firestone, M.K., Paul, E.A., 1992. Decomposition and nutrient dynamics of ponderosa pine needles in a Mediterranean type climate. Can. J. For. Res. 22, 306314.

Heyerdahl, E.K., Alvarado, E., 2002. Influence of climate and land use on historical surface fires in pine oak forests, Sierra Madre Occidental, Mexico. In: Veblen, T.T., Baker, W.L., Montenegro, G., Swetnam, T.W. (Eds.), Fire and Climatic Change in Tempe rate Ecosystems of the Western Americas. Springer Verlag, New York.

Kalra, Y.P., Maynard, D.G., 1991. Methods manual for forest soil and plant analysis. For. Can., Northwest Reg., North. For. Cent., Edmonton, Alberta. Inf. Re. NOR X 319, 116 pp..

Maloney, P.E., Rizzo, D.M., 2002. Pathogens and insects in a pristine forest ecosystem: the Sierra San Pedro Martir, Baja. Mexico. Can. J. For. Res. 32, 448457.

Markham, C.B., 1972. Baja California's climate. Weatherwise 25, 6476.

Mast, J.N., Covington, W.W., Fule, P.Z., Moore, M.M., Waltz, A.E.M., 1999. Restoration of presettlement age structure of an Arizona ponderosa pine forest. Ecol. Appl. 9, 228 239.

McCune, B., Grace, J.B., 2002. Analysis of ecological comm unities. MjM Software Design. Gleneden Beach, Oregon, p. 300 .
McGarigal, K., Cushman, S., Stafford, S., 2000. Multivariate Sta tistics for Wildlife and Ecology Research. Springer Verlag, New York, NY.

Millar, C.I., Woolfenden, W.B., 1999. The role of climate change in interpreting historical variability. Ecol. Appl. 9, 12071216.

Miller, C., Urban, D.L., 1999. Forest pattern, fire, and climatic change in the Sierra Nevada. Ecosystems 2, 7687.

Minnich, R.A., Barbour, M.G., Burk, J.H., Fernau, R.F., 1995. Sixty years of change in California conifer forests of the San Bernar dino Mountains. Conserv. Biol. 9, 902914.

Minnich, R.A., Franco Vizcaino, E.F., Sosa Ramirez, J., Burk, J.H., Barry, W.J., Barbour, M.G., de la Cueva Salcedo, H., 1997. A land above: protecting Baja California's Sierra San Pedro Martir within a Biosphere Reserve. J. Southwest 39, 613695.

Minnich, R.A., Franco, E., 1998. Land of Chamise and Pines: Historical Accounts and Current Status of Northern Baja Cali fornia's Vegetation, vol. 80. University of California Publica tions in Botany, 166 pp..

Minnich, R.A., Barbour, M.G., Burk, J.H., Sosa Ramirez, J., 2000. Californian mixed conifer forests under unmanaged fire regimes in the Sierra San Pedro Martir, Baja, California, Mexico. J. Biogeogr. 27, 105129.

Moore, M.M., Covington, W.W., Fulé, P.Z., 1999. Reference con ditions and ecological restoration: a Southwestern ponderosa pine perspective. Ecol. Appl. 9, 12661277.

NWCG, 2001. Review and update of the 1995 federal wildland fire management policy. National Wildfire Coordinating Group. Interagency Fire Center, Boise, ID.

O'Hara, K.L., Seymour, R.S., Tesch, D.D., Guldin, J.M., 1994. Silviculture and our changing profession: leadership for shifting paradigms. J. For. 92, 813.

O'Hara, K.L., Latham, P.L., Hessburg, P., Smith, B.G., 1996. A structural classification for inland northwest forest vegetation. West. J. Appl. For. 11, 97102.

Oliver, C.D., 1981. Forest development in North America following major disturbances. For. Ecol. Manage. 3, 153168.

Potter, D.A., 1998. Forested communities of the upper montane in the central and southern Sierra Nevada. USDA Forest Service General Technical Report PSW 169, 319.

Pyke, C.B., 1972. Some meteorological aspects of the seasonal distribution of precipitation in the western United States and Baja California. University of California Water Resources Cen ter Contribution No. 139. Los Angeles, CA.

Quinby, P.A., 1991. Self replacement in old growth white pine forest of Temagami, Ontario. For. Ecol. Manage. 41, 95109.

Reyes Coca, S., Miranda Reyes, F., Garcia Lopez, J., 1990. Clima tologia de la Region Noroeste de Mexico. Parte I Precipitacion: Series de tiempo del valor total mensual y estadisticas del ano climatologicogico. Grupo de Meteorologia, Centro de Investi gación Científica y de Educación Superior de Ensenada (CICESE). Comision Nacional del Agua. Reporte Tecnico CIOFIT9001. Ensenada, Baja California, Mexico.

Santoro, A.E., Lombardero, M.J., Ayres, M.P., Ruel, J.J., 2001. Interactions between fire and bark beetles in an old growth pine forest. For. Ecol. Manage. 144, 245254.

Savage, M., 1997. The role of anthropogenic influences in a mixed conifer forest mortality episode. J. Veg. Sci. 8, 95104. 
Sheil, D., Burslem, D.F.R.P., Alder, D., 1995. The interpretation and misinterpretation of mortality rate measures. J. Ecol. 83, 331 333.

Skinner, C.N., Chang, C., 1996. Fire regimes, past and present. In: Sierra Nevada Ecosystem Project: Final report to Congress, vol. II. Assessments, Scientific Basis for Management, Options, Wildland Resources Center Report No. 37, Centers for Water, Wildland Resources, University of California, Davis, CA, pp. 10411069.

Stambaugh, M.C., Muzika, R., Guyette, R.P., 2002. Distur bance characteristics and overstory composition of an old growth shortleaf pine (Pinus echinata Mill.) forest in the Ozark Highlands, Missouri. U.S.A. Nat. Areas J. 22, 108 119.

Stephens, S.L., 2001. Fire history of adjacent Jeffrey pine and upper montane forests in the Eastern Sierra Nevada. Int. J. Wildland Fire 10, 161167.

Stephens, S.L., 2004. Fuel loads, snag density, and snag recruitment in an unmanaged Jeffrey pine mixed conifer forest in north western Mexico. For. Ecol. Manage. 199, 103113.

Stephens, S.L., Collins, B.M., 2004. Fire regimes of mixed conifer forests in the north central Sierra Nevada at multiple spatial scales. Northwest Sci. 78, 1223.

Stephens, S.L., Skinner, C.N., Gill, S.J., 2003. Dendrochronology based fire history of Jeffrey pine mixed conifer forests in the Sierra San Pedro Martir, Mexico. Can. J. For. Res. 33, 1090 1101 .
Stephenson, N.L., 1999. Reference conditions for giant sequoia forest restoration: structure, process, and precision. Ecol. Appl. $9,12531265$.

Sumner, M.E., Miller, W.P., 1996. Cation exchange capacity and exchange coefficients. In: Sparks, D.L. (Ed.), Methods of Soil Analysis, Part 3. Soil Science Society of America, Inc., Madi son, WI, pp. 12011229.

Swetnam, T.W., Baisan, C.H., Kaib, J.M., 2001. Forest fire histories of the sky islands of La Frontera. In: Webster, G.L., Bahre, C.J. (Eds.), Changing Plant Life of La Frontera: Observations on Vegetation in the United States/Mexico Borderlands. University of New Mexico Press, Albuquerque, NM, pp. 95123.

Taylor, A.H., 1998. Reconstruction of pre Euroamerican forest structure, composition, and fire history in the Carson Range, Lake Tahoe Management Unit. Final report, cooperative agree ment 0024 CA 95. USDA For. Serv. Pac. Southwest. For. Ran. Exp. Station, Berkeley, CA.

USDA, 2004. Sierra Nevada Forest Plan Amendment, final supple mental environmental impact statement, R5 MB 019. USDA Forest Service Pacific Southwest Region, Vallejo, CA.

Zack, S., Laudenslayer, W.F., George, T.L., Skinner, C., Oliver, W., 1999. A prospectus on restoring late successional forest struc ture to eastside pine ecosystems through large scale, interdisci plinary research. In: Cook, J.E., Oswald, B.P. (Eds.), First Biennial North American Forest Ecology Workshop. Society of American Foresters, Forest Ecology Working Group, Bethesda, MA, pp. 343355 . 